\title{
Practice and politics: Ethics and social responsibility in SMEs in the European Union
}

\author{
Laura J. Spence \\ Francesco Perrini
}

\begin{abstract}
In this paper we outline the status quo of ethics and social responsibility in small and medium sized enterprises (SMEs) in the European Union (EU). Social issues and SMEs is an established topic of research and subject of policy-making in Europe, and thus in this paper we are able to draw on existing activities to summarise what we know about the topic. We describe the important position given to SMEs and entrepreneurship as drivers of the economy through job creation, social inclusion and issues such as employee health and welfare. We note that the ethics/social responsibility practices and strategies of SMEs tend to be greater than expected, but are informal and local community-based rather than replicating large firm approaches. To demonstrate the variety within Europe, we provide some nation-specific perspectives on social responsibility and SMEs with a closer look at Denmark, Italy, the UK and central and eastern Europe and the Baltic States.
\end{abstract}

Key words: SMEs, Europe, European Union, social responsibility, CSR, business ethics

\section{Introduction}

The different cultural, economic and linguistic traditions make it difficult in a sense to talk of a single European approach to anything, not least business ethics. However, what we can do is note the similarities within Europe, which distinguish it as a group of countries from other regions (Spence, 2000a). Despite its heterogeneity,

Laura J. Spence is Director of the Centre for Research into Sustainability (CRIS) at Royal Holloway, University of London, where she is a Reader in Business Ethics. She is section editor of the Journal of Business Ethics for Small Business, Entrepreneurship and Social Enterprise. Dr Spence is Vice President of the International Society for Business, Economics and Ethics (www.isbee.org). Her most recent book is CSR: Readings and Cases in Global Context edited with Andrew Crane and Dirk Matten (Routledge, 2008).

Francesco Perrini is Full Professor of Management and SIF Chair of Social Entrepreneurship and Philanthropy Management at the Institute of Strategy, Department of Management, Bocconi University, Milan, Italy. He is also Director of the CSR Unit and of the Bachelor of Business Administration and Management at Bocconi. Francesco is Senior Professor of Corporate Finance at the SDA Bocconi School of Management. Since 1990 he has been a researcher at SPACE Bocconi, focusing on 'Strategic and Innovation Management of Corporate Development Processes' (strategy implementation, acquisitions management; financial strategies and valuation; SMEs) and 'Social Issues in Management' (corporate governance, sustainability, social responsibility, CSR, SRI, sustainable innovation and social entrepreneurship).
Europe has a degree of common intellectual and cultural heritage. Furthermore, unlike other regions most of the countries $^{1}$ of Europe are governed increasingly by a common governmental framework in the form of the European Union (EU), and it is these countries that we focus on here. In December 2007 the signing of the Treaty of Lisbon further strengthened the ties between the countries of the EU.

The EU has a population of nearly half a billion. It was first conceived as a means of keeping peace between the frequently warring countries of Europe after the Second World War (European Union, 2009a). As such, it has at its heart the twin goals of economic prosperity and social cohesion, both of which mean that the business ethics and corporate social responsibility movements have been well received and indeed embraced by the administrative centre of Europe, the European Commission.

The semantics and terminology around social and ethical responsibility in European business is a problematic one. Within Europe the fields of corporate social responsibility (CSR) and ethics exist to some extent in parallel. There is no clear delineation in Europe of the meaning of or difference between these two concepts. The research which we report on here is termed both CSR and business ethics respectively. Nevertheless, it is the CSR terminology familiar in Anglophone which has been adopted at the European level, and which we accordingly broadly follow here with one important adjustment. Where SMEs are concerned there is a serious problem with the corporate social responsibility terminology, in that most SMEs are not corporations, i.e. they have neither limited liability nor are they legal entities in their own right. Indeed, SMEs are unlikely to use any recognisable language of CSR, including the acronym itself (Murillo \& Lozano, 2006; Spence \& Lozano, 2000). The CSR terminology has become the dominant refrain in this area, although it is worth noting that the phrase 'responsible business' appears to be gaining some currency (Moore \& Spence, 2006; Southwell, 2004). We prefer to drop the corporate implication and talk instead of 'social responsibility', by which we intend to keep small and medium sized enterprises within the mainstream CSR debate. We adapt Aguilera et al.'s (2007) definition of social responsibility as being 'the firm's considerations of, and response to, issues beyond the narrow economic, technical, and legal requirements of the firm to accomplish social [and environmental] benefits along with the traditional economic gains which the firm seeks'. 
Previous to the more active political involvement in CSR at the level of the European Union, in continental Europe social issues have tended to be addressed from the macro level, setting the constraints for business at the level of institutional frameworks and regulation, i.e. focusing on the 'rules of the game' (Enderle, 1996). This means that conditions are created for an implicit form of CSR (Matten \& Moon, 2008) and has been suggested as a peculiarly European approach (Matten \& Moon, 2005) compared to a US version of CSR, which is explicit in terms of corporate policies. Hence government, trade unions and corporate associations are the key actors (Crane \& Matten, 2007:32). The change in Europe in recent years has been to adopt a more explicit, US approach $^{2}$, bringing to the fore that which has long existed in the background (Matten \& Moon, 2008). This is reflected in the European Alliance of CSR, which is presented at the end of this paper and represents a shift of focus putting the onus on voluntary corporate initiatives.

Small and medium sized enterprises are an explicitly acknowledged part of the European Union approach to CSR, being seen as 'a major source of entrepreneurial skills, innovation, and [that contributes] to economic and social cohesion' (CEC, 2005:3). In the European region generally, SMEs are a recognised part of economic life, although they do not necessarily feature explicitly in all policy and wider business initiatives. From a research perspective there is a thriving body of literature on SMEs though there remains a lack of theorising and impact on the mainstream management literature (Blackburn \& Kovalainen, 2009).

In this paper we present the standard European definition of SMEs and locate their role in society. We use previous research to summarise SME social responsibility practices and highlight differences from large firms. Since Europe is not a single political, economic and social arena, we seek to demonstrate some of the internal differences by focusing on some specific example countries, taking in a Mediterranean country, one from northern Europe, the Anglo-Saxon example of the UK and the transition economies of central and eastern Europe and the Baltic States. With much political interest in seeking to influence SMEs to engage in social responsibility activities, we summarise the initiatives taken and recommend further courses of action. We take a look at environmental perspectives also. Finally we look at future developments in the social responsibility and SMEs' field in Europe.

\section{Defining SMEs}

While there is much disagreement on the definition of small and medium sized enterprises in the literature (Curran \& Blackburn, 2001), there is a reasonably clear proposal from the European Union, as shown in Table
1. Following this definition, there are 19 million small and medium sized enterprises in the region representing $99.8 \%$ of all EU enterprises and employing more than 74 million people (European Union, 2009b).

TABle 1: Definition of SMALL AND MEDIUM SIZED ENTERPRISE IN THE EUROPEAN UNION

\begin{tabular}{llll}
\hline Enterprise category & Head count & Turnover & or Balance sheet total \\
\hline Medium & $<250$ & $\leq € 50$ million & $\leq € 43$ million \\
\hline Small & $<50$ & $\leq € 10$ million & $\leq € 10$ million \\
\hline Micro & $<10$ & $\leq € 2$ million & $\leq € 2$ million \\
\hline
\end{tabular}

Source: European Union (2009c)

The parameters shown in Table 1 are not, however, universally accepted, resulting in different standards used in research projects, rendering comparison problematic. Curran and Blackburn (2001:8-19) detail the problems of defining small firms. They advocate an approach combining qualitative and quantitative perspectives, and remaining conscious of sector differences. Nevertheless, given the importance of cross-country comparison, it is the EU definition, which we would recommend when taking a broad perspective such as we do in this paper.

\section{Role of SMEs in society}

As Raynard and Forstater (2002:3) point out:

CSR represents not just a change to the commercial environment in which individual SMEs operate but also needs to be considered in terms of its net effect on society. If CSR, as some critics believe, introduces social and environmental clauses resulting in protectionism by the back door, imposes inappropriate cultural standards or unreasonably bureaucratic monitoring demands on small businesses, the net effect on the communities concerned will be a reduction in welfare. On the other hand, CSR offers opportunities for greater market access, cost savings, productivity and innovation to SMEs, as well as broader social benefits such as education and community development.

The net effect of social responsibility for SMEs remains unclear. Indeed, this is true of larger organisations too, despite the plethora of publications investigating corporate social performance (see Orlitzky et al., 2003). However, it not our purpose to pursue this issue here with only one study thus far which has conclusive results on this within Europe ${ }^{3}$.

The perceived importance of SMEs in Europe is not in doubt at the political level. The Vice President of the European Commission in charge of Enterprise and Industry claimed in 2007 that 'it is no exaggeration to say that in two years, Europe's 23 million SMEs have become the centre of interest not only at the EU level 
but also in the Member States.' (Verheugen, 2007:8) He refers in particular to the fact that of the six million new jobs between 1998 and 2004, five million were created in SMEs (Verheugen, 2007:2). This primary social contribution of SMEs, that of job creation, is of critical importance to Europe, as elsewhere, hand-in-hand with the goal of social inclusion.

Going beyond this perspective, the social role of SMEs becomes more unclear. Spence (2000b), however, found that over $50 \%$ of SME owner-managers in a UK survey felt that their social contributions included (in order of frequency stated): caring for employee health and welfare, good role modelling, supporting local business, giving to charity through the business, caring for the environment, supporting the local community, supporting their industry, as well as generating employment for others. This list is a commendable recognition of the social responsibility work that SMEs do.

In the next section we identify some of the issues around SMEs and their social contribution. These should be considered against the backdrop of a development in the EU, which offers the potential for SMEs to move still closer to the centre stage of European approaches called the Small Business Act. This was promoted as a priority for the Commission in 2008, institutionalising the 'Think Small First' rhetoric commonly promoted in the EU. Furthermore, it encompasses a drive away from close regulation of SME activity (Verheugen, 2007:9). The Small Business Act for Europe was adopted by the European Commission in the summer of 2008, recognising the central role of SMEs in the EU economy.

However, it should be noted that there is a conundrum here. On the one hand, research shows a great deal of small-scale empirical evidence of implicit social responsibility, on the other hand policy makers are targeting them for change. SMEs, characterised by a desire for independence and freedom from intervention and bureaucracy (Goffee \& Scase, 1995), are not prone to responding to government initiatives. This raises the challenge of how best to influence SMEs, not least since many already exhibit socially responsible practices.

\section{Ethics/social responsibility practices within SMEs}

Research on ethics and social responsibility from the SME perspective is significantly different from the research based on large firm practices (e.g. Jenkins, 2006; Tilley, 2000). Nevertheless, the CSR of SMEs has received relatively little attention (for exceptions see Grayson, 2004; Moore \& Spence, 2006; Morsing \& Perrini, 2009; Perrini, 2006; Perrini et al., 2007; Russo \& Tencati, 2008; Spence, 1999; Spence et al., 2000; Spence \& Lozano, 2000; Spence \& Rutherfoord, 2001; 2003; Spence \& Schmidpeter, 2003; Spence et al., 2003; Thompson \& Smith, 1991; Vyakarnam et al., 1997). This is not only a challenge in the study of social responsibility, but is endemic in management research more generally, where small businesses are often considered a minority activity, contrary to the evidence.

Research focusing on the SME relationship to social responsibility in Europe has highlighted that SMEs are less likely to adopt and develop explicit social responsibility strategies than their larger counterparts. Graafland, van de Ven, and Stoffele (2003) suggest that small firms make less use of CSR instruments than do large firms mainly because of four motivations: visibility to the public and the media; economies of scale; more need for instruments that facilitate the communication of values and norms within the firm and to their customers; and stronger competitiveness in the output market for small enterprises. Moreover, CSR tools signify a greater proportional investment of time, finances and energy for the small firm than for large firms (Spence et al., 2000). In general, as has already been alluded to, research repeatedly suggests that SMEs are engaging in CSR, but have a different profile compared to large firms (Moore \& Spence, 2006; Perrini et al., 2007). This is an extremely important point for understanding the position of SMEs in the analysis of social responsibility and business ethics in Europe. They are not necessarily the problem case, which they are sometimes portrayed to be. Perrini, Russo and Tencati provide more detailed evidence noting that large firms are more likely to address environmental management, employment, local communities, and controlling and reporting strategies. In contrast, SMEs reveal a stronger willingness to recognise the importance of responsible behaviour throughout the supply chain. Russo and Tencati (2008) distinguish between sizes of SME, and find that micro firms (with up to ten employees) reveal their CSR aptitude through strategies with a significant impact on the bottom line, for example, their commitment to eco-efficiency (i.e. reduction of consumption and pollution reduction strategies). Moreover, micro firms support initiatives that encourage stakeholder engagement, which can be seen to exemplify their attempt to secure a social licence to operate in the communities.

What this recent research in Europe suggests is that SMEs are subject to a number of distinctive and intrinsic characteristics that make them different from their larger counterparts, therefore affecting the content, nature and extent of their social responsibility activities. Drawing together much of the previous work on SMEs in this field in Europe, the following aspects can be identified as important (adapted from Spence, 2007):

- a lack of codification of social responsibility in small businesses (Jenkins, 2004; Spence, 1999);

- personal motivations for taking socially responsible initiatives are more important than marketing, strategic, or public relations approaches (Jenkins, 2004; Spence, 2000b);

- owner-manager acts as both principal and agent of the firm (Quinn, 1997; Spence \& Rutherfoord, 2001); 
- small businesses are often embedded in their local communities (Perrini, 2006; Spence et al. 2003; Tencati et al. 2004);

- flexibility, personal service and reputation are important competitive factors for SMEs (Spence, 1999; 2000b; 2004);

- employees are the key stakeholders (Janjuha-Jivraj, 2003; Jenkins, 2004; Spence, 2000b); and

- sector context is particularly important (Curran \& Blackburn, 2001; Spence \& Schmidpeter, 2003).

While these factors are probably not limited to Europe, they were all identified in research on SMEs within the EU. Future research should investigate the extent to which these aspects of ethics and social responsibility in relation to SMEs are quintessentially European or otherwise.

A vast array of recent reports on social responsibility (CERFE Group, 2001; CSR Campaign, 2003; Raynard \& Forstater, 2002; WBCSD, 1999) conclude with the clear direction for further research on social responsibility to provide SMEs with guidance and tools that enable them to implement and report on their socially responsible policies, processes and performance in an effective manner. This somewhat instrumental managerialist approach is in keeping with the dominant policy discourse around CSR in which the SME perspective remains embedded.

\section{Country-specific traits: Denmark, Italy, the UK and central and eastern Europe and the Baltic States}

Understanding a phenomenon across Europe cannot be done without reference to individual national approaches, and social responsibility is no exception (Habisch \& Jonker, 2005:2). We have pointed out the similar cultural heritage across Europe. Despite the similarities that bind Europe together, national differences remain, though we believe that these do not overwhelm the similarities, such that it is still meaningful to compare Europe to other regions such as North America or Africa. Nevertheless, as Enderle (1996:36) points out, 'talk about morality and business is deeply culture bound and language-dependent'. In addition to the EU wide social responsibility initiatives to which all member states are subjected, several European countries seek to encourage initiatives by diffusing social responsibility amongst SMEs, and many initiatives have been promoted at the national level and by different types of organisation.

Here, we focus on a sample of countries to help give some texture to the wider European perspective we have presented: Italy (one of the classic southern countries of Europe with a Mediterranean flavour); Denmark (one of the north European countries with a highly developed welfare system); the UK (with its Anglo-
Saxon perspective drawing it close on occasion to the US approach); and finally the group of countries which are known as CEEBS (central and eastern Europe and the Baltic States, which are new capitalist economies seeking to make sense of Westernised systems in relation to their communist pasts).

\section{Denmark - north European}

Denmark has long been known in Europe for its highly developed welfare system, which is primarily aimed at ensuring constant social welfare over time through generous transfer schemes, high-quality services and a comprehensive educational system, all with a decidedly public makeup (CEC, 2007a). In the early 1990s, this led to extensive reforms in employment policy, setting the threefold objective of preventing exclusion from the workforce, creating the conditions for maintaining one's job, and expanding/improving the possibilities of reintegrating those who have been unemployed for long periods of time, individuals with limited job skills and so on. This landscape of profound change and redesign of social policy comprises the Danish government's initiatives regarding social responsibility (Jorgensen \& Knudsen, 2006). A decisive stance in the debate on the importance for companies to move beyond mere observance of the law in corporate management was taken in 1994 with the campaign 'Our Common Concern - The Social Responsibility of Companies', promoted by the Ministry for Social Affairs. This initiative defined the government's official role in promoting the dissemination of CSR, which is to encourage social partnerships and research in order to reduce social exclusion and achieve an inclusive labour market. The emphasis on the importance of adopting actions based on partnership, which is the core of Danish public policy, is based on the belief that social challenges must be faced by focusing on co-operation between the players influenced by these challenges and those who can influence them. More specifically, public initiatives to promote corporate social responsibility are designed around the dissemination of knowledge, information campaigns and research, and other initiatives aimed at creating public-private partnerships.

The most significant initiative in the area of partnerships for the promotion of responsibility was the establishment in June 1998 of The Copenhagen Centre (TCC), which is an independent body created after the World Summit on Social Development held in Copenhagen in 1995 and the Danish CSR campaign. TCC acts as an intermediary among public authorities, businesses (including SMEs), trade unions and social organisations and is primarily responsible for stimulating public debate, co-operation between the social partners, and the sharing of experiences by conducting studies, organising and facilitating networks, and publishing reports, all in order to 'make CSR real'. 
In such a context of social responsibility interactions among companies and organisations, Nelson and Zadek (2001) proposed a definition of partnership as 'people and organisations from some combination of public, business and civil constituencies who engage in common societal aims through combining their resources and competencies' sharing both risks and benefits. This work supports the notion mentioned previously that small organisations have a strong preference for non-formal responsible practices (CEC, 2003b): only very few Danish enterprises point to, for example, formal training practices as more important in comparison to non-formal training practices. National literature provides a number of reasons for this strong preference for non-formal training practices: lower costs (Koch \& van Straten, 1997), ease of integration of this training into the enterprise's everyday activities, or its easier focus on the worker's specific individual and work role needs (Curran et al., 1997).

The Danish focus on social responsibility and SMEs was heightened with the publicly funded People \& Profit project which ended in 2006 on Mainstreaming CSR in SMEs which focused particularly on competitiveness, knowledge dissemination, training and growth and found that socially responsible activities by Danish SMEs enhanced competitiveness (Kramer et al., 2005). As part of this work a mapping was done in 2005 of social responsibility in SMEs, which found that the most common areas of activity were workforce, environmental and charity/socially orientated and that ethical and moral reasons were the main drivers. Notably, firm size increase correlated with increased importance of financial gain and customer requirements as drivers.

\section{Italy - Mediterranean and southern Europe}

Starting from an intense debate on social responsibility issues, which had emerged at the European level (CEC, 2001; 2002), the Italian Ministry of Welfare launched in June 2002 an innovative and ambitious project on the social responsibility of enterprises (Tencati et al., 2004). The initiative, called Corporate Social Responsibility - Social Commitment (CSR-SC), has the aim of promoting the involvement of Italian enterprises in social responsibility activities, with particular attention on SMEs. The framework of the project had to incorporate some general goals, broadly discussed with the Ministry of Welfare and other stakeholders, including: promoting a social responsibility culture among businesses; guaranteeing citizens that the reporting of corporate social commitment by companies is true and not misleading; defining a simple and modular standard that firms can adopt on a voluntary basis in order to identify socially responsible behaviour; and preparing a list of relevant performance indicators to measure the social performance of companies.

Specific attention was dedicated to SMEs from the very beginning of the project. Another important initiative is that by Unioncamere (the Italian association of Chambers of Commerce) and the Italian Ministry of Welfare who have established a network of CSR 'information desks' to develop CSR information and training services in local and regional chambers of commerce (Grayson \& Dodd, 2007:6).

In fact, a comparison with the average size of European companies shows the peculiarity of the Italian system (CEC, 2003a) such that:

- there are an average of 3.9 employees in Italian businesses compared to an average of six employees per firm overall for the $15 \mathrm{EU}$ member states; and

- industrial enterprises with over 250 employees account for $19.7 \%$ of the total in Italy and $34 \%$ of the total for the EU.

As shown and analysed in a broad range of literature (e.g. Perrini et al., 2007; Russo \& Tencati, 2008), the particular features highlighted above have historically influenced the diffusion of managerial tools and standards in Italy. A well-known example is the diffusion of the ISO standards on total quality management (ISO 9001, 1994) and environmental management systems (ISO 14001) and the voluntary environmental regulations such as EMAS (Eco-Management and Audit Scheme). In particular, Perrini, Russo and Tencati (2007) found that Italian firms are conscious of the importance of taking seriously both complaints and expectations of different categories of stakeholders; nevertheless, while implementing specific social responsibility strategies, firms do not recognise the same relevance of such different stakeholders. Moreover, they found that size explains the differences in firms' willingness to define and implement such specific social responsibility strategies, since formal CSR approaches still seem to be a prerogative of large firms. Regarding this latter point, Russo and Tencati (2008) provided evidence that firms still seem to approach social responsibility as an attempt to secure a licence to operate in their own community, therefore highlighting that differences exist between firms of different sizes at a twofold level: first, in the absence of formalising social responsibility strategies; and second, in the approach to responsible behaviours toward specific categories of stakeholders.

Given the above context, evidence suggests that the Italian approach to social responsibility involves a nationally widespread network of interventions and actions that are highly innovative (Perrini et al., 2006b). It is indeed true that many of the voluntary activities carried out by companies, mostly SMEs despite a strong relationship with the local community - are scarcely systematic; that is, they are not structured into formalised strategic processes, and they have low visibility outside the company. This common approach to social responsibility in Italy, which can be defined as a sort of 'sunk CSR' (Perrini et al., 2006a), is a frequent phenomenon that cannot easily be appreciated and enhanced for use by conventionally competitive multinational corporations. 


\section{UK - Anglo-Saxon}

The United Kingdom is unusual in the EU in that it has a Minister for CSR in the UK government, although the profile of this has diminished in recent years with it now being part of a much wider portfolio. The government role in terms of social responsibility is seen 'to raise awareness; provide an enabling environment encouraging businesses to adopt responsible business practice both at home and in their international operations and support and encourage adherence to international standards (CEC, 2007a:89-91). Government sponsored research on social responsibility and SMEs resulted in a practical, web-based toolkit for SMEs on social responsibility and ethics issues launched in 2004 - www. smallbusinessjourney.com. This initiative is run by the Small Business Consortium. This consortium emerged in response to calls by UK SME for guidance on a coherent approach to social responsibility. The consortium consists of AccountAbility, Arts \& Business, British Chambers of Commerce, Business in the Community, CSR Europe, Federation of Small Businesses, The Forum of Private Business, Institute of Directors, Lloyds TSB and Scottish Business in the Community (www.csr.gov.uk). In the $\mathrm{UK}$, there is government level recognition that SME approaches to social responsibility and business ethics are different from large firms, and attempts are made to accommodate this through instruments and tools. A remaining problem, however, is that this level of awareness is not always true of large corporations which are increasingly aware of supply chain risks in terms of social responsibility and are pushing social responsibility requirements down the supply chain as a form of risk management.

A number of research studies on UK SMEs have found very encouraging instances of socially responsibility activities, although these tend not to be documented or publicised (Jenkins, 2006; 2009; Southwell, 2004; Spence, 2000b). Spence and Rutherfoord (2001) found that rather than the primary motivator for small businesses being the profit motive, they commonly balance social goals and profit 'satisficing' activities. Though limited, research on social issues and ethics in the flourishing ethnic minority business group (Janjuha-Jivraj, 2003; Worthington et al., 2006), and in social enterprises, has also begun to develop in the UK (Cornelius et al., 2007).

\section{Central and eastern Europe and the Baltic States}

The central eastern European and the Baltic States, among the newer member states of the $\mathrm{EU}$, are in a process of profound structural change. Once the decisive break with communism was made in the early '90s, SME development has been the cornerstone of economic reform policies pursued by all governments in the region (CEC, 2003a). A number of studies on
CEEBS small and medium sized enterprises revealed that these countries have a very different situation compared to other European countries, because they are still in the process of transition towards a true market economy (Van Stel, Carree \& Thurik, 2004). Thus, the exact impact of SMEs on economic growth is not generic, but rather idiosyncratic, in that the impact is shaped by the level of economic development of the specific country. From a conceptual point of view, Audretsch and Thurik (2001) explained the different roles SMEs play in countries with different levels of economic development. They use 14 dimensions and distinguish between the model of the entrepreneurial economy and the model of the managed economy.

The central and eastern European and Baltic States are also aware of social responsibility and the important SME perspective. This is being promoted by the United Nations Development Programme (funded by UNDP and the European Commission), which launched a regional project to accelerate CSR development in the new and candidate member states, Bulgaria, Croatia, Hungary, Lithuania, Macedonia, Poland, Slovakia and Turkey. Since beginning the process of joining the $\mathrm{EU}$, the CEEBS have tended to focus on economic development, with less attention on environmental and social concerns; 'Privatization and the new economic agenda resulted in "wild capitalism", where profit became the most important goal for most companies in the region.' (Line \& Braun, 2007:21) Whereas western European business is in the process of bringing social responsibility to the mainstream, here 'some business leaders are just becoming familiar with the term, while others have started a step-bystep approach to integrating CSR into their business practices. For a vast number of SMEs, CSR is still a very distant challenge, which falls outside their business priorities. The fragmented understanding of the CSR concept is frequently linked to piecemeal philanthropy, rather than to core business or market positioning' (Accelerating CSR, 2009). In a study of the region to identify an understanding of the baseline of social responsibility, Line and Braun (2007) found that it is the businesses, rather than governments or other bodies who are leading change in this area, despite the socialist heritage, which would point to government as the stewards of social responsibility and welfare.

Across each of the European countries discussed in this section we see government or inter-governmental level intervention to seek to facilitate social responsibility in small and medium sized enterprises specifically. While empirical work is more developed in western Europe (represented by Italy, UK and Denmark in this case) compared to central and eastern Europe and the Baltic States, what we see is evidence of SME activity in social responsibility supported by the individual country's small business and political infrastructures. In CEEBS these are naturally less well developed as a result of the 
relatively recent move to a capitalist economy, hence it is unsurprising that the intergovernmental initiatives are the drivers. Common to all areas is a recognition of the relevance and importance for SMEs to engage with social responsibility. Unclear at this stage, however, is an accurate understanding of how best to do this.

\section{Influencing SMEs}

In light of the above considerations, research has recently taken due account of a knowledge gap in the social responsibility-SME relationship. Nevertheless, there is still inadequate knowledge of the business case, obstacles and drivers of social responsibility in European SMEs. Therefore, building a solid body of evidence could be a major contribution to furthering uptake of social responsibility among small businesses. Similarly, many European SME owner-managers and entrepreneurs (not to mention members of large multinationals) still do not have the competences and tools to manage firms in a responsible way. In particular, SMEs need to understand the relevance of social responsibility to their business.

In 2002, the European Commission approved and launched the establishment of the European MultiStakeholder Forum on CSR as the centrepiece of the commission strategy for promoting CSR and sustainable development. The Forum aimed to foster CSR, promoting innovation, transparency and convergence of CSR practices and instruments. It worked through improving knowledge about the relationship between CSR and sustainable development (including its impact on competitiveness, social cohesion and environmental protection). This was done by facilitating the exchange of experience and good practices and bringing together existing CSR instruments and initiatives, with a special emphasis on SME specific aspects. Additional initiatives included: exploring the appropriateness of establishing common guiding principles for CSR practices and instruments; taking into account existing EU initiatives and legislation and internationally agreed instruments such as OECD Guidelines for multinational enterprises, the Council of Europe Social Charter, ILO core labour conventions and the International Bill of Human Rights. Going more in depth into the social responsibility-SME relationship, the Forum recognised:

... that for SMEs where there is a heavy turnover of new entrants and businesses ceasing to trade; where most face intense daily pressures to survive; and where they face what may often seem like a constantly changing and extensive range of regulatory requirements, then simply meeting relevant environmental and social legislation will be a substantial commitment. There is a widespread fear amongst SMEs about additional regulatory burdens. All this needs to be appreciated in any discussion of CSR and SMEs. Sometimes too, heavy demands placed on SMEs at the end of long supply chains can translate into pressure to cut costs in such a way that social and/or environmental responsibilities are jeopardised. (European Multi-Stakeholder Forum on CSR, 2004:65).

Accordingly, Table 2 shows the base upon which the Forum recognised the need for promoting CSR among SMEs.

Table 2: European Multi-StaKeholder Forum ROUND TABLE ON SMES - SOME CONSIDERATIONS

CSR SMEs initiatives need to be better grounded in SME reality and therefore:

- easily accessible, with relevant and quality advice;

- tailored to SMEs;

- available through channels that are known and trusted by SMEs, including sector specific trade associations;

- not bureaucratic;

- using language, examples and concepts to which SMEs can easily relate;

- flexible and a willing to go at the pace of individual SMEs - some will find it easier to adopt a step-by-step approach with CSR unpacked to component parts; and

- above all, to be delivered as close to the market and the customer as possible.

'Many SMEs are driven to integrate CSR because of the personal beliefs and values of the founders / owner-manager(s) and employees. This will be most obvious in co-operatives and other social enterprises where the core purpose of the business may be a social goal; but it holds true for many other SMEs too. Additionally/alternatively, many SMEs are driven by some combination of minimising risks and maximising opportunities:

- Attracting, retaining and developing motivated and committed employees - especially because the speed of market and technology change means need flexible and engaged staff;

- Winning and retaining consumers and business customers (supply chain pressures and opportunities) especially because economic stagnation means SMEs need to find new markets/revenue streams;

- Being a good neighbour - maintaining a licence to operate from the local community;

- Responding to pressures from banks and insurers;

- Reputation - with internal and external stakeholders;

- Changing perceptions of the role of business in society (not only a source of profit), through the media, education, and actions by stakeholders;

- Cost and efficiencies savings e.g. reduced insurance and landfill costs;

- Networking opportunities;

- Product/market innovation, differentiation, and competitive edge; and the need for more sources of creativity and innovation in business;

- Anticipating future legislation/getting practical experience of compliance in ways that help business.'

Source: European Multi-Stakeholder Forum on CSR (2004)

The key message that should be transferred to relevant actors is that social responsibility is not a shortcut to business success, but an investment that can pay off in the longer term. It can bring advantages, for example in terms of staff retention and recruitment, staff development and motivation, customer loyalty and reduced expenditure on energy. If social responsibility can contribute to the competitive advantage of the firm, then it can also contribute to the competitiveness of the socio-economic context in which firms operate. In particular, competitiveness depends on the productivity that a country, region or group of businesses active in any given territory draws from the human, financial and natural resources at its disposal. 
Given that SMEs are a fundamental part of the growth and jobs equation (CEC, 2006), if CSR can contribute to regional competitiveness, this implies a need to focus on the social responsibility practices of SMEs, the businesses most closely associated with the regions and territories where they operate. Where social responsibility can provide SMEs with a comparative advantage, then particular attention must be paid to economies of scale with regard to cost, to the accessibility of CSR instruments and to the exchange of good practices within a specific context. We could argue that European SMEs have always been very close to what we call today 'CSR' (Perrini et al., 2007). Through their typically local anchoring, they are well placed to make a strong contribution to socio-economic development at a local level and act as responsible members of a community. Nevertheless, different actors, in the first place persons and organisations that work with and for SMEs, such as business support organisations, SME or sector representative organisations, trade unions, networks and non-governmental organisations, but also policy-makers, have to address this need from the viewpoint of SMEs themselves and then rightly underline the need to make social responsibility relevant and practical.

The European Commission also supports the analysis and dissemination of information about socially responsible practices through social partners, business networks and professional associations. Going beyond past initiatives, there is a common feeling about the need for increasing the quality and quantity of initiatives taken to support the uptake of social responsibility amongst SMEs. There does seem to be a groundswell of initiatives in Europe often regionally based, with even an EU award for the best initiative promoting 'Responsible and Inclusive Entrepreneurship' (European Union, 2009d). In addition to initiatives already mentioned in this paper, Grayson and Dodd (2007:6-7) identify: Xertatu (supported by the Basque regional Government, the Bilbao Chamber of Commerce and other academic and non-governmental stakeholders in Spain (Xertatu, 2009)); Fabrica Etica (Tuscany leather-goods cluster regional initiative in Italy (Fabrica Ethica, 2009)); Vaderegio Regional Authorities network (Vaderegio, 2009); Unternehmen: Partner der Jugend (UPJ Organisations: Partners of Youth), a network in Germany that promotes social responsibility amongst businesses and experiments in building cross-sector partnerships to enable businesses to contribute to solving societal problems such as youth unemployment (UPJ, 2009). Grayson and Dodd report activities carried out under the banner of these initiatives as including 'surveys on attitudes to, and practice of, CSR in SMEs; collection of case studies; training for SMEs; development of CSR guides and management systems for SMEs; training material and capacity-building for SME "intermediaries"; and analysis of supply-chain issues. CSR award schemes with SME categories are increasingly common'.

\section{SMEs and sustainability}

The European Union perspective on sustainability incorporates economic, social and environmental pillars, all linked with competitiveness, set in the framework of the Lisbon Strategy for Growth and Jobs launched in 2005. Social responsibility and sustainability are seen as linked since 'CSR is also part of the glue that binds the Growth and Jobs Strategy into our overall objective of sustainable development' (Verheugen, 2005). Grayson and Dodd (2007) argue that 'sustainability' may be a more helpful term than 'CSR' for smaller businesses. In 2007, Verheugen noted that '[w]e have not yet built the flexible, innovative, knowledge-based and environment friendly economy which will guarantee the long-term sustainability of our way of life' (2007:3). Therefore, CSR represents the main economic-social driver of business sustainability, that is, the capability of the firm to generate long-term value through mutually beneficial relationships with its entire network of stakeholders, 'business stakeholders' and 'socio-political stakeholders' (Perrini et al., 2006b). Here we concentrate on the environmental perspective of sustainability.

While there are legislative frameworks for environmental protection, individual SMEs often fall below the threshold for compliance or are not aware that they are not compliant (CEC, 2007b:3-4). Barriers to European SMEs engaging with eco-efficiency include lack of awareness of environmental problems or of the potential benefits of environmental management; insufficient access to information, expertise and tools; short-term planning; limited market incentives for environmentally aware behaviour and the macro-level governing of environmental issues (CEC, 2007b:4).

An Environmental Compliance Assistance Programme adopted in 2007 aimed at alerting Europe's 23 million SMEs not only to the negative impact that their daily business can have on the environment, but also to the business opportunity that a change in behaviour can present. This programme has a simple, if somewhat naïve, motivating message for SMEs: 'Go Green, Go Rich' (Verheugen, 2007:11). The elements of the plan include:

- better regulation in design and implementation of policies, to facilitate and minimise the administrative burden of compliance for SMEs and free their resources for improving compliance;

- more accessible tailor-made environmental management schemes, to integrate environmental concerns into the core business activities of SMEs in a coherent and cost-effective way;

- focused financial assistance and a multi-annual financial programme, to promote and support initiatives by public authorities or business support networks aiming at sustainable production in SMEs;

- building local environmental expertise for SMEs, to overcome the lack of know-how at company level; and 
- improved communication and more targeted information, to address specific information gaps. (CEC, 2007b)

Clearly, at the European level, an awareness of the challenge for sustainability and environmental compliance for SMEs has arisen and a concerted effort is now being made to address these concerns. The next stage would be to go beyond the notion that environmental responsibility is profitable and seek to ingrain a more complex understanding, yet acceptance, of the vital importance of sustainability.

\section{Current and new developments}

On 22 March 2006 the European Commission published a new communication entitled 'Implementing the partnership for growth and jobs: Making Europe a pole of excellence on corporate social responsibility'. In this document the Commission underlines the strong relationship between social responsibility, globalisation, competitiveness and sustainability (CEC, 2006:1): 'The Commission is committed to promoting the competitiveness of the European economy in the context of the re-launched Lisbon Partnership for Growth and Jobs. In turn it calls on the European business community to publicly demonstrate its commitment to sustainable development, economic growth and more and better jobs, and to step up its commitment to CSR, including cooperation with other stakeholders.' The Alliance is clearly defined as a 'political process to increase the uptake of CSR amongst European enterprises' (CEC, 2006:3).

According to the Commission, sustainable growth and more and better jobs are the two main related challenges which the European Union must face in a context of global competition and an ageing population to safeguard the European model of society, based on equal opportunities, high quality of life, social inclusion and a healthy environment. In this respect 'CSR can contribute to sustainable development, while enhancing Europe's innovative potential and competitiveness, thereby also contributing to employability and job creation. Further promoting CSR is central to the new partnership for 'growth and jobs' as well as for implementing sustainable development objectives' (CEC, 2006: 8).

The communication on the European Alliance for CSR is the last step of a process begun in February 2005 when the Commission fostered a new start for the Lisbon Agenda by launching a Partnership for Growth and Jobs and continued in December 2005 by revising the Sustainable Development Strategy (CEC, 2005). The communication confirms that CSR is fundamentally about voluntary business behaviour: an approach entailing additional obligations and administrative burdens for companies is considered counter-productive and contrary to the principles of improved regulation. The Alliance is a political umbrella for new or existing initiatives carried out by large companies and SMEs, and their stakeholders. It is not a legal instrument and is not signed by firms, the Commission or public authorities. The crucial concept underlying this initiative is partnership. Hence, the Alliance is intended as a vehicle for mobilising the resources and capacities of European companies and their stakeholders to promote CSR. Three business organisations are acting as support platforms for the European Alliance on CSR, helping to co-ordinate its work and to provide feedback to the European Commission and other interested parties: CSR Europe, BusinessEurope, and UEAPME (European Association of Craft, Small and Medium sized Enterprises). Helping SMEs to flourish and grow is one of ten priority areas for the alliance. At the time of writing it is too early to evaluate the success of this initiative.

\section{Conclusion}

Throughout the last few decades, the European economic scene has been continuously changing. Each change influences actors at different levels (i.e. policy makers, governments, organisations, and individuals). In this context, a great deal of attention has been paid to the social responsibility and commitment characterising a firm's strategic mission and behaviour. Following government indications as well as developing their own voluntary actions, firms are showing their willingness to adopt socially responsible behaviour, in that these might have direct and indirect effects on the socio-economic context in which they operate.

In such a dynamic context, 'CSR' is defined as a new managerial model centred on the voluntary integration of economic, social and environmental responsibilities into the entire value chain and all company functions, and on the relationships with the stakeholder network. CSR is a discipline through which the progressive alignment of shareholder and stakeholder interests is satisfied, along with a shift from short- to long-term objectives (Perrini et al., 2006b).

At a more institutional level, the EU has been actively dealing with these issues since 2001, when it presented the Green Paper, 'Promoting a European framework for CSR'. Since the inclusion of CSR in the European political agenda as one of the most relevant sources of competition for the entire economic system, each country's interest in CSR, at both the public and private level, has grown exponentially. There is now a steady stream of research and reports on social responsibility and SMEs coming from the EU.

In this paper, we have presented two parallel paths: one encompasses the efforts of policy makers and organisations to spread the idea of socially responsible behaviour and CSR practices through initiatives, and 
formal definitions. The other path includes academic research, which has progressed from an initial, vague awareness of the relationship between companies and social/environmental issues to the identification of a more defined set of management tools and rules of conduct.

In this context, the most challenging area of intervention remains the promotion of the actual adoption of CSR among enterprises, in particular SMEs. Surveys indicate that lack of awareness, especially of the relevance and benefits of CSR for every business, is a major obstacle to the promotion of social responsibility in Europe. Despite the successes to date, many issues remain to be tackled in order to raise further general awareness of social responsibility in SMEs in Europe.

\section{Notes:}

${ }^{1}$ Some 27 countries are members of the EU at the time of writing. The main exceptions being Norway, Switzerland, Turkey and the former states of the USSR and some of the former states of Yugoslavia.

${ }^{2}$ We acknowledge that US corporate policies are at least in part inspired by government regulation such as the Sarbanes-Oxley Act 2002 and the Federal Sentencing Guidelines.

3 We will mention later the research by Kramer, Pfitzer, Lee (2005) which found a positive connection between social responsibility activity and Danish SMEs.

\section{References}

Accelerating CSR. 2009. Accelerating CSR in new Europe. [Online]. Available: http://www.acceleratingcsr.eu/en/ about. Accessed on 9 December 2009.

Aguilera, R., Rupp, D., Williams, C. \& Ganapathi, J. 2007. Putting the ' $\mathrm{S}$ ' back in corporate social responsibility: A multi-level theory of social change in organizations. Academy of Management Review, 32(3): 836-863.

Audretsch, D.B. \& Thurik, R. 2001. What's new about the new economy? Sources of growth in the managed and entrepreneurial economies. Industrial and Corporate Change, 10(1): 267-315.

Blackburn, R. \& Kovalainen, A. 2009. Researching small firms and entrepreneurship: Past, present and future. International Journal of Management Reviews, 11(2): 127148.

CEC (Commission of the European Communities). 2001. Green Paper. Promoting a European framework for corporate social responsibility. Brussels, Belgium: Commission of the European Communities.

CEC (Commission of the European Communities). 2002. Corporate social responsibility: A business contribution to sustainable development. Brussels, Belgium: Commission of the European Communities, COM 347 final.

CEC (Commission of the European Communities). 2003a. Observatory of European SMEs. SMEs in Europe 2003. Brussels, Belgium: Commission of the European Communities, Enterprise Publications, 2003/7.
CEC (Commission of the European Communities). 2003b. Observatory of European SMEs. Competence development in SMEs. Brussels, Belgium: Commission of the European Communities, Enterprise publications, 2003/1.

CEC (Commission of the European Communities). 2005. Implementing the Community Lisbon Programme Modern SME Policy for Growth and Employment. Communication from the Commission to the Council, the European Parliament, the European Economic and Social Committee and the Committee of the Regions, COM 551.

CEC (Commission of the European Communities). 2006. Implementing the partnership for growth and jobs: Making Europe a pole of excellence of corporate social responsibility. Communication from the Commission to the European Parliament, the Council and the European Economic and Social Committee, COM 136 final.

CEC (Commission of the European Communities). 2007a. Corporate social responsibility: National public policies in the European Union. Directorate-General for Employment, Social Affairs and Equal Opportunities.

CEC (Commission of the European Communities). 2007b. Small, clean and competitive: A programme to help small and medium-sized enterprises comply with environmental legislation. Communication from the Commission to the Council, the European Parliament, the European Economic and Social Committee and the Committee of the Regions, COM 379 final.

CERFE Group. 2001. Action research on corporate citizenship among European small and medium enterprises. CERFE Laboratory.

Cornelius, N., Todres, M., Janjuha-Jivraj, S., Woods, A. \& Wallace, J. 2008. Corporate social responsibility and the social enterprise. Journal of Business Ethics, 81(2): 355-370.

Crane, A. \& Matten, D. 2007. Business ethics: Managing corporate citizenship and sustainability in the age of globalization. Oxford: Oxford University Press.

CSR Campaign. 2003. The European business campaign for corporate social responsibility. Brussels: European Union.

Curran, J. \& Blackburn, R. 2001. Researching the small business. London: Sage.

Curran, J., Blackburn, R., Kitching, J. \& North, J. 1997. Small firms and workforce training: Some results, analysis and policy implications from a national survey. In M. Ram, D. Deakins \& D. Smallbone, Small firms. Enterprising futures. London, UK: Paul Chapman.

Enderle, G. 1996. A comparison of business ethics in North America and continental Europe. Business Ethics: A European Review, 5(1): 33-46.

European Union. 2009a. Basic information on the European Union. [Online]. Available: http://europa.eu/abouteu/basic-information/index_en.htm. Accessed on 9 December 2009.

European Union. 2009b. Definition of Small and MediumSized Enterprises. [Online]. Available: http://ec.europa. eu/enterprise/consultations/sme_definition/index.htm. Accessed on 20 August 2009.

European Union. 2009c. SME Definition. [Online]. Available: http://ec.europa.eu/enterprise/policies/sme/facts-figuresanalysis/sme-definition/index_en.htm. Accessed on 9 December 2009. 
European Union. 2009d. [Online]. Available: http:// ec.europa.eu/enterprise/entrepreneurship/smes/awards/ awards/. Accessed 24 August 2009.

European Multi-Stakeholder Forum on CSR. 2004. Corporate social responsibility: Final results and recommendations. Brussels, Belgium: Commission of the European Communities.

Fabrica Ethica. 2009. Fabrica Ethica. [Online]. Available: www2.fabricaethica.it/. Accessed on 24 August 2009.

Goffee, R. \& Scase, R. 1995. Corporate Realities. London: Routledge.

Graafland, J., van de Ven, B. \& Stoffele, N. 2003. Strategies and instruments for organising CSR by small and large businesses in the Netherlands. Journal of Business Ethics, 47(1): 45-60.

Grayson, D. 2004. How CSR contribute to the competitiveness of Europe in a more sustainable world. The World Bank Institute and the CSR Resource Centre, (Netherlands): 1-5.

Grayson, D. \& Dodd, T. 2007. Small is sustainable (and beautiful!) - Encouraging European smaller enterprises to be sustainable. Occasional Paper, The Doughty Centre for Corporate Responsibility, Cranfield School of Management, UK. [Online]. Available: www. doughtycentre.info. Accessed on 24 August 2009.

Habisch, A. \& Jonker, J. 2005. Introduction by Habisch, A., Jonker, J., Wegner, M. \& Schmidpeter, R. (eds.) Corporate social responsibility across Europe. Berlin: Springer. pp. $1-12$.

Janjuha-Jivraj, S. 2003. The sustainability of social capital within ethnic networks. Journal of Business Ethics, 47(1): 31-43.

Jenkins, H. 2004. A critique of conventional CSR theory: An SME perspective. Journal of General Management, 29(4): 37-57.

Jenkins, H. 2006. Small business champions for Corporate Social Responsibility. Journal of Business Ethics, 67(3): 241-256.

Jenkins, H. 2009. A 'business opportunity' model of corporate social responsibility for small and medium sized enterprises. Business Ethics: A European Review, 18(1): 21-36.

Jorgensen, A.L. \& Knudsen, J.S. 2006. Sustainable competitiveness in global value chains: How do small Danish firms behave? Corporate Governance: The International Journal of Effective Board Performance, 6(4): 449-462.

Koch, C.L.Y. \& van Straten, E. 1997. Personnel Management within a Few SMEs. EIM, Strategic study B9703, Zoetermeer.

Kramer, M., Pfitzer, M. \& Lee, P. 2005. Competitive social responsibility: Uncovering the economic rationale for corporate social responsibility among Danish small- and medium-sized enterprises. Foundation Strategy Group \& Center for Business and Government, John F. Kennedy School of Government, Harvard University. [Online]. Available: http://www.eogs.dk/sw26505.asp. Accessed on 20 August 2009.

Line, M. \& Braun, R. 2007. Baseline study on CSR practices in the new EU members states and candidate countries. UNDP and the European Commission. [Online]. Available: http://www.acceleratingcsr.eu/uploads/docs/BASELINE STUDY_ON.pdf. Accessed on December 132007.
Matten, D. \& Moon, J. 2005. A conceptual framework for understanding CSR. In A. Habisch, J. Jonker, M. Wegner, $\&$ R. Schmidpeter (eds.) Corporate social responsibility across Europe. Berlin: Springer. pp. 335-356.

Matten, D. \& Moon, J. 2008. 'Implicit' and 'explicit' CSR - A conceptual framework for a comparative understanding of corporate social responsibility. Academy of Management Review, 33(2): 404-424.

Moore, G. \& Spence, L.J. 2006. Responsibility and small business. Journal of Business Ethics. 67(3): 219-226.

Morsing, M. \& Perrini, F. (guest eds.) 2009. CSR in SMEs: Do SMEs matter for the CSR agenda? Business Ethics $A$ European Review, 18(1): 1-6.

Murillo, D. \& Lozano, J. 2006. SMEs and CSR: An approach to CSR in their own words. Journal of Business Ethics, 67(3): 227-240.

Orlitzky, M., Schmidt, F.L. \& Rynes, S.L. 2003. Corporate social and financial performance: A meta-analysis. Organization Studies, 24(3): 403-441.

Nelson, J. \& Zadek, S. 2001. Partnership alchemy: New social partnerships in Europe. Copenhagen, Denmark: The Copenhagen Centre.

People \& Profit 2006. Report Summary. [Online]. Available: http://ec.europa.eu/enterprise/csr/documents/ mainstreaming/ms_sme_topic2_gadegaard.pdf. Accessed on 20 August 2009.

Perrini, F. 2006. SMEs and CSR theory: Evidence and implications from an Italian perspective. Journal of Business Ethics, 67(3): 305-316.

Perrini, F., Pogutz, S. \& Tencati, A. 2006a. Corporate social responsibility in Italy: State of the art. Journal of Business Strategies, 23(1): 65-91.

Perrini, F., Pogutz, S. \& Tencati, A. 2006b. Developing corporate social responsibility: A European perspective. Cheltenham, UK: Edward Elgar Publishing.

Perrini, F., Russo, A. \& Tencati, A. 2007. CSR strategies of SMEs and large firms: Evidence from Italy. Journal of Business Ethics, 74(3): 285-300.

Quinn, J.J. 1997. Personal ethics and business ethics: The ethical attitudes of owner/managers of small business. Journal of Business Ethics, 16(2): 119-127.

Russo, A. \& Tencati, A. 2008. Formal vs. informal CSR strategies: Evidence from Italian micro, small, mediumsized, and large firms. Journal of Business Ethics, (forthcoming).

Raynard, P. \& Forstater, M. 2002. Corporate social responsibility: Implications for small and medium enterprises in developing countries. Vienna: United Nations Industrial Development Organization.

Southwell, C. .2004. Engaging SMEs in community and social issues. In L.J. Spence, A. Habisch, \& R. Schmidpeter. Responsibility and social capital: The world of small and medium sized enterprises. Basingstoke: Palgrave Macmillan.

Spence, L.J. 1999. Does size matter? The state of the art in small business ethics. Business Ethics: A European Review, 8(3): 163-174.

Spence, L.J. 2000a. Teaching business ethics: Are there differences within Europe and is there a European difference? Review of 'the European Difference' by Zsolnai, L. Business Ethics: A European Review, (9)1: 58-64. 
Spence, L.J. 2000b. Practices, priorities and ethics in small firms. London: Institute of Business Ethics.

Spence, L.J. 2004. Small firm accountability and integrity. In G. Brenkert (ed.) Corporate Integrity and Accountability, London: Sage. pp. 115-128.

Spence, L.J. 2007. CSR and small business in a European policy context: The five Cs of CSR and small business research agenda 2007. Business and Society Review, 112(4): 533-552.

Spence, L.J. \& Lozano, J.F. 2000. Communicating about ethics with small firms: Experiences from the UK and Spain. Journal of Business Ethics, 27(1): 43-53.

Spence, L.J., Jeurissen, R. \& Rutherfoord, R. 2000. Small business and the environment in the UK and the Netherlands: Toward stakeholder cooperation. Business Ethics Quarterly, 10(4): 945-965.

Spence, L.J. \& Rutherfoord, R. 2001. Social responsibility, profit maximisation and the small firm owner-manager. Small Business and Enterprise Development, Summer 8(2): 126-139.

Spence, L.J. \& Rutherfoord, R. .2003. Small business and empirical perspectives in business ethics: Editorial. Journal of Business Ethics, 47(1): 1-5.

Spence, L.J. \& Schmidpeter, R. 2003. SMEs, social capital and the common good. Journal of Business Ethics, 45(1-2): 93-108.

Spence, L.J., Schmidpeter, R. \& Habisch, A. 2003. Assessing social capital: Small and medium sized enterprises in Germany and the U.K. Journal of Business Ethics, 47(1): 17-29.

Tencati, A., Perrini, F. \& Pogutz, S. 2004. New tools to foster corporate socially responsible behavior. Journal of Business Ethics, 53(1-2): 173-190.

Thompson, J.K. \& Smith, H.L. 1991. Social responsibility and small business: Suggestions for research. Journal of Small Business Management, 29 (January): 30-44.

Tilley, F. 2000. Small firms' environmental ethics: How deep do they go? Business Ethics: A European Review, 9(1): $31-41$.

UPJ. 2009. Willkommen. [Online]. Available: www.upj.de. Accessed on 9 December 2009.

Vaderegio, 2009. Vaderegio: CSR in action in the regions. [Online]. Available: www.csrvaderegio.net/. Accessed on 24 August 2009.

van Stel, A., Carree, M. \& Thurik, A. 2004. The effect of entrepreneurship on national economic growth: An analysis using the Gem database. GEM research conference. 1-3 April, Berlin, Germany.

Verheugen, G. 2005. Corporate social responsibility matters-tomorrow even more than yesterday or today. CSR - Competitive, small, responsible conference. 14 June, Brussels.

Verheugen, G. 2007. SMEs and entrepreneurship - successful local strategies. Porto Conference. 7 December, Portugal.

Vyakarnam, S., Bailey, A., Myers \& Burnett, D. 1997. Towards an understanding of ethical behaviour in small firms. Journal of Business Ethics, 16(15): 1625-1636.

WBCSD (World Business Council for Sustainable Development). 1999. Corporate social responsibility: Meeting changing expectations. Conches-Geneva. [Online]. Available: http://www.wbcsd.org/plugins/DocSearch/ details.asp?type=DocDet\&ObjectId=Mjg2. Accessed on 21 July 2001.

Worthington, I., Ram, M. \& Jones, T. 2006. Giving something back: A study of corporate social responsibility in UK South Asian small enterprises. Business Ethics: A European Review, (15)1: 95-108.

Xertatu 2009. About Xertatu. [Online] Available: h t t p : / / w w w. xertat u.net/i n_plantilla. asp?idMenu=25\&cambioIdioma=s. Accessed on 24 August 2009.
Address correspondence to: Laura J. Spence Centre for Research into Sustainability Royal Holloway University of London TW20 OEX, UK e-mail: laura.spence@rhul.ac.uk Francesco Perrini Bocconi University Institute of Strategy Department of Management Viale Filippetti 9 20122 Milan Italy e-mail: francesco.perrini@unibocconi.it 
Reproduced with permission of the copyright owner. Further reproduction prohibited without permission. 